\title{
Atividade Antioxidante e Teores de Fenóis e Flavonoides Totais do Extrato Etanólico Obtido do Caule de Smilax sp.
}

\author{
Izabela C. A. Silva*, Juliana C. Fonseca, Álan A. Aleixo, Ana Hortência \\ F. Castro, Joaquim M. Duarte-Almeida, Luciana A. R. dos Santos Lima
}

\author{
Universidade Federal de São João Del-Rei - UFSJ - Campus Centro-Oeste Dona Lindu- \\ Divinópolis/MG. \\ email: izacaputo@hotmail.com
}

\section{Resumo}

Os vegetais superiores sintetizam e acumulam uma grande diversidade de compostos fenólicos, cujo papel no metabolismo da planta ainda não está inteiramente esclarecido. A família Smilacaceae possui distribuição predominante nos climas tropical e subtropical, incluindo dois gêneros e cerca de 300 espécies, quase todas pertencentes à Smilax. No Brasil, apenas o gênero Smilax é encontrado, com aproximadamente 30 espécies, conhecidas popularmente como salsaparrilha ou japicanga. Espécies do gênero Smilax ainda são pouco estudadas. Assim, o presente estudo teve como objetivo avaliar a atividade antioxidante e determinar quantitativamente os teores de fenóis e flavonoides totais a partir do extrato etanólico obtido dos caules de Smilax sp. Os caules de Smilax foram coletados, secados e triturados. O extrato etanólico foi obtido por percolação com etanol e avaliado quanto à atividade antioxidante, a partir do método do DPPH (2,2-difenil-1-picril-hidrazil). A análise foi feita a partir de concentrações de 500, 250,100, 10 e $1 \mu \mathrm{g} / \mathrm{mL}$ do extrato, sendo lida a absorbância após 30 minutos em espectrofotômetro a 517 nm. Ensaios espectrofotométricos foram realizados para determinar o teor de fenóis e flavonoides totais, expressos como mg equivalentes de ácido gálico e de quercetina/mL, respectivamente. O extrato etanólico de Smilax apresentou uma alta porcentagem de inibição de DPPH em todas as concentrações testadas, variando de $51,37 \%$ a $95,84 \%$, nas concentrações de 1 a $500 \mu \mathrm{g} / \mathrm{mL}$. Na análise de fenóis totais foi obtido o teor de $22,97 \mathrm{mg}$ equivalentes de ácido gálico/mL, já na análise de flavonoides totais obteve-se um teor de 7,15 mg equivalentes de 
quercetina/mL. Dessa forma verificou-se que os caules de Smilax sp. possuem potencial antioxidante e altos teores de fenóis e flavonoides totais, sugerindo futuramente o possível uso como fonte de antioxidantes naturais.

Palavras-chave: Smilax, atividade antioxidante, fenóis, flavonoides.

Apoio financeiro: CNPq, FAPEMIG, UFSJ. 